\title{
SASKATCHEWAN BIRD SPECIES - HYPOTHETICAL AND REJECTED
}

C. STUART HOUSTON, MARY I. HOUSTON, 863 University Drive, Saskatoon Saskatchewan S7N 0J8, and J. BERNARD GOLLOP, Canadian Wildlife Service 115 Perimeter Road, Saskatoon, Saskatchewan. S7N 0X4

At the beginning of 1981 there were 339 fully accepted species of birds on the Saskatchewan list. In addition, there were 39 "hypothetical" species, 29 of these being additions since the fifth Field Check-list of Saskatchewan Birds in 1969. The following list of the hypothetical species is, we believe, complete to 1 January 1981, using the same cutoff date as we used in the last issue for fully accepted species (Blue Jay 39:145-154, September 1981).

The word "hypothetical" in its conventional ornithological usage is quite specific - it means a species claimed to have been seen but for which there is no material evidence, such as a specimen, a recognizable photograph or an unmistakable sound recording. A "hypothetical" species is one that can neither be fully accepted or fully rejected on the evidence available. The following list contains records of varying degrees of validity and credibility, each of which must be judged individually on its merits, bearing in mind the circumstances and the reputation of the observer(s). Some are highly probable for one reason or another, but even if we were to identify a record that we thought had only a $10 \%$ chance of being right, this would be rather meaningless. It is something like quoting a $10 \%$ mortality rate to a patient, this figure being of little solace when the patient dies. Just as the patient either lives or dies, so is the bird identification either $100 \%$ right or $100 \%$ wrong. It is just that we do not know for sure which of these possibilities is true, for there is no proof. Nevertheless, the easier a species is to identify, the bette the conditions, the better the observe the more likely it is to be correct. An when more observers in more places more times see the same species, the the probability becomes very high in deed, even though it is entirely possibl for many observers to make the sam error at different times.

A "hypothetical" record is not to $k$ confused with a "rejected" recor Records for five "rejected" species an another that we rejected before it $g$ into print, are given at the end of the a ticle. Any "nearly acceptable" categor is still arbitrary, but one could defer five well documented sightings $b$ different observers as a minimum for

A panel sitting in judgment on suc records might assess probabilities $a b$ more accurately than any one individu but, as with an observer, mistakes woul be made, and such errors could receiv unwarranted credibility. Some of th records judged as valid by such a com mittee would be in error; some of $t r$ records rejected by them would, in fac have been correct. We admit that erro have been made even with materi evidence, but at least the specimen, th photograph or the sound tape al available for reassessment and corres tion.

We leave the reader to place his her own valuation on each of $t h$ following, but we reiterate that not one the following records is as yet fu acceptable. 
Because the list of references would take more space than the list itself, and because this is more of an index than a review article, we have forsaken tradition and have placed the reference immediately after each sighting or group of sightings. Single birds are involved and all reports are sight records unless otherwise specified. New refers to a species added since the fifth check-list.

1. YELLOW-CROWNED NIGHT HERON. NEW. An adult 20 May 1978 at Lebret Marsh by Frank H. Brazier, E. Manley Callin and David Chaskavich (Blue Jay 36:145146, 1978).

2. GLOSSY IBIS. NEW. Based on detailed field notes by P.M. Browne, on 14 August 1979 about 5 mi north of Courval, noting the differentiating features between the Whitefaced Ibis and this species. A photograph clearly demonstrates this to be an Ibis, but the photo does not reveal the diagnostic markings (Kreba, Blue Jay, this issue).

3. EUROPEAN WIGEON. NEW. Four sightings: a pair on 7 May 1971 at Cumberland House by D.T. Little (Blue Jay 29:134, 1971); a male 6, 7 and 8 June 1975 at a farm dugout north of Moose Jaw by V.J. Lieffers and D.R.M. Hatch (Qu'Appelle Waterfowl Resource Inventory, Wildlife Tech. Rep. 77 20, 1977, p. 47); an adult male through spotting scope at $100 \mathrm{~m}$ on 27 April 1977 at the east end of Cypress Lake by F.M. Brigham and J.D. Lafontaine (Blue Jay 35:170, 1977); 23 May 1977 at Moose Jaw y M.A. Ritchie and R.O. Hilling (Serr, Am. irds 31:1014, 1977).

4. COMMON POCHARD. NEW. A pair on 11 June 1977 at Stonybeach Lake, $8 \mathrm{mi}$ porth of Belle Plaine, by Frank Brazier and FImer Fox (Blue Jay 36:216-217, 1978).

5. BARROW'S GOLDENEYE. Four ecords, two before the fifth Check-list in 1969: an adult male 6 April 1956 at Morse by lohn M. Nelson (Nero, Blue Jay 23:127, 1965) and an adult male shot but not verified At Pasqua Lake on 12 October 1964 by lamie Young (Nero, Blue Jay 23:127, 1965); male on 9 November 1975 north of Semans py Wayne C. Harris (Serr, Am. Birds 30:87, 976); a male through a spotting scope at Fastend on 5 and 6 April 1980 by Jack and anet Wilkinson (Gollop, Am. Birds 34:788, 980).
6. SWALLOW-TAILED KITE. All but one of the six sightings were before the first Check-list in 1947: in the 1880's at Fort Qu'Appelle by R.H. Hunter; on 24 May 1890 at Fort Qu'Appelle by George Lang; on 9 June 1898 at Katepwa by George Lang, and near Regina on 20 June 1906 by George Lang (Callin, Birds of the Qu'Appelle 18571979, 1980, p. 60); an adult in April 1921, 3.5 mi northwest of Tisdale by Stanley J. Street and Maurice G. Street (Blue Jay 29:224-225, 1971); in spring of 1955 in Regina by E.L. Fox (Belcher, Birds of Regina, 1980, p. 49).

7. RED-SHOULDERED HAWK. NEW. 17 August 1980 at Wolseley by J. Donald Hayward (Harris, Am. Birds 35:195, 1981).

8. MOUNTAIN PLOVER. NEW. Elliott Coues in his survey immediately south of the 49th parallel in 1874, reported: "Its centre of abundance in the region was the vicinity of Frenchman's River, where many specimens, both adult and young, together with a set of three eggs, were secured during the first and second weeks in July." (Coues, Bull U.S. Geol. \& Geog. Survey Terr., 4: 1878, p. 634). First Canadian sighting was on 5 June 1939 near Bracken by J.D. Soper (Can. Field-Nat. 55:137, 1941). Eight on 22 September 1977 near Val Marie by Bob Peart and J.G. Woods (Blue Jay $38: 41,1980$ ). An undated sighting by John Shadick about 1959, south of Govenlock has not been published.

9. AMERICAN WOODCOCK. Was on first list and then withdrawn. There are unusually dubious sightings for Woodcock: Portage on the Fond du Lac River by J.B. Tyrrell on 8 August 1892, quoted by Nero (Birds of the Lake Athabasca region, 1963, p. 72), vague reports of possible sightings at Oxbow and Moose Mountain by Mitchell (Birds of Saskatchewan, Canadian Field-Nat. 38:106, 1924), and a sighting in the Qu'Appelle east of Craven by Sylvia Harrison and Pearl Guest in 1960 (Blue Jay 16:160, 1960). Bob Kreba heard one or two on the shore of Little Kenosee Lake, Moose Mt. Provincial Park, on 5 and 6 May 1978 (pers. comm.)

10. ESKIMO CURLEW. First listed in fifth check-list, Godfrey (Birds of Canada, 1966, p. 145) says "it undoubtedly occurred", and Gollop (mss.) concurs. An unnamed companion of Walter Raine gave a tantalizing record of "nearly a hundred" birds in May 1891 (Houston, Blue Jay 39:172, 1981). Although four specimens were collected during the first Franklin expedition, 1819-1821, 
all were outside of Saskatchewan. However, Richardson in his reasonably reliable table, giving sight records for Carlton and Cumberland during the two Franklin expectition, says "Of passage, spring." (Fauna BorealiAmericana, II, 1831, pp. xxviii-xxix.).

11. SHARP-TAILED SANDPIPER. NEW. Two on 24 May 1980 at Regina by Robert Kreba and Tom Riffel, studied for 25 minutes at 30 feet with a $60 x$ scope. (Gollop, Am. Birds 34:788, 1980; date wrong).

12. WESTERN SANDPIPER. NEW. Five sightings: More than once in spring 1968 at Regina by Bill Eddie (Belcher, Birds of Regina, 1980, p. 68); on 25 July 1974 at Perdue by A.R. \& Karen Smith; (Renaud and Renaud, Birds of the Rosetown-Biggar district, Saskatchewan, 1975 , p. 66-67); four at Catherwood Lake near Perdue within $35 \mathrm{ft}$ on 30 May 1977 by G.J. and R.A. Wapple and R. Chulach (Blue Jay 35:158, 1977); two near Biggar on 15 May 1978 (Belcher, Birds of Regina, 1980 , p. 68); and on 18 May 1980 at Moose Jaw by J. Thomson (Gollop, Am. Birds, 34:788, 1980).

13. BLACK-NECKED STILT. Was on third and fourth lists, but stricken from fifth. The supposed nest record for 3 June 1894 at Qu'Appelle is not an acceptable record (Godfrey, Auk 86:562-563, 1969). There are three sightings: three birds by Peter McLellan near Arcola on 20 May 1955 (Blue Jay 13(3):21-22), one by D. Renaud near Rosetown on 7 May 1971 (Renaud \& Renaud, Birds of the Rosetown-Biggar dis- trict, 1975, p. 69-70) and five by Wayne Harris near Willowbunch on 6 August 1980 (Harris, Am. Birds, 35:195, 1981).

14. LONG-TAILED JAEGER. Was on fifth list. Five records: Kazan Lake on 13 June 1942 by T.E. Randall, harrying terns at close range (Blue Jay 20:67, 1962); Lake Athabasca on 1 July 1959 by W. Emblau and two on 25 July 1962 by R.W. Nero (Nero, Birds of the Lake Athabasca region, 1963, p. 80); north of Big Sandy Lake on the Bear River on 14 June 1972 by $G$. Anweiler, unpubl.; Condie Reservoir on 5 September 1977 by F.W. Lahrman (Belcher, 1980, p 70).

15. ICELAND GULL. NEW, though on previous list when Thayer's Gull was considered a subspecies of Iceland Gull. Three sightings: two immatures 23-24 September 1977 at Saskatoon by Muriel and Geof Galloway and six other observers (Serr, Am Birds 32:222, 1978); 23 December 1979 a Squaw Rapids by Wayne Harris (Blue Jay 38:20, 28-29, 1980), and 24-25 April 1980 a Katepwa Lake by Frank and Margie Brazier E.M. Callin and DRM Hatch (Callin, Birds o the Qu'Appelle, 1857-1979, 1980, p. 159).

16. LESSER BLACK-BACKED GULI NEW. Within $20 \mathrm{ft}$ on 28 May 1977 nea Regina by Frank and Margie Brazier (Blue Jay 35:257-258, 1977).

17. LAUGHING GULL. NEW. Two flev over highway near Lake Chaplin on 9 July 1975 seen by D.B.O. and C.E. Savile (Can Field-Nat. 90:187, 1976).

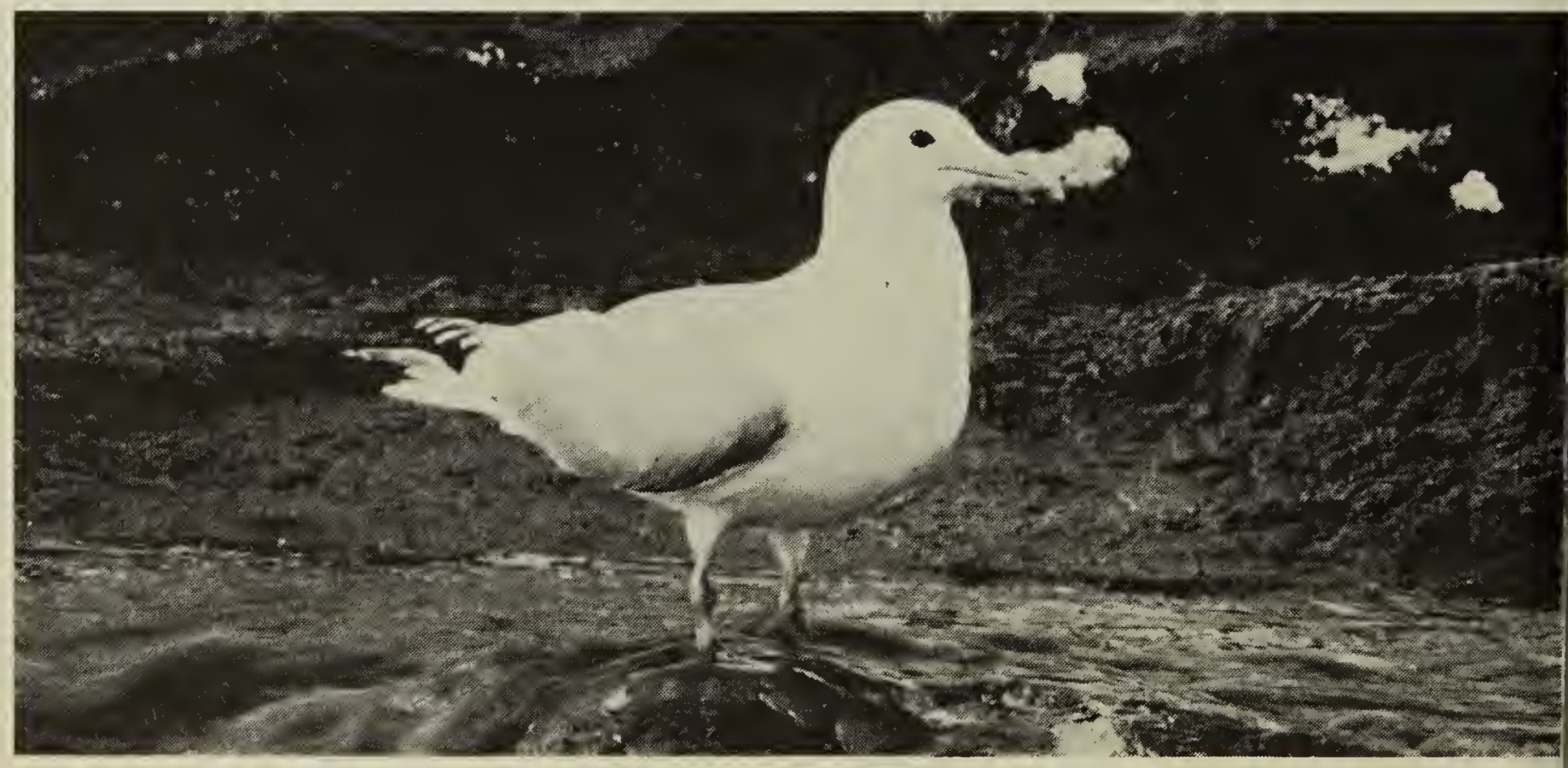


18. IVORY GULL. NEW. Five at Nemieben Lake on 16 September 1976 by F.G. Bard (Lahrman, Blue Jay 35:49, 1977).

19. LEAST TERN. On fifth check-list. On 26 May 1957 by Frank Brazier and Elmer Fox near Regina (Blue Jay 18:162, 1960).

20. BAND-TAILED PIGEON. NEW. Three sightings: 6 August 1970 at Valley Centre near Rosetown by Wayne and Don Renaud (Blue Jay 28:166, 1970); in Saskatoon on 30 September 1970 by Shelagh Aldous (Shadick, Blue Jay 33:167, 1975), and 28-29 June 1980 near Mortlach by B. Forbes (Gollop, Am. Birds 34:905, 1980).

21. YELLOW-BILLED CUCKOO. NEW. One sighting on 8 June 1974 near Estevan by T.M. Beveridge (Houston, Am. Birds 28:917, 1974).

22. ANNA'S HUMMINGBIRD. NEW. One seen intermittently from 21 June to about 8 August 1971 in garden south of Raymore by Greta Harris (unpublished, pers. comm.).

23. BLACK-CHINNED HUMMINGBIRD. NEW. Seven feet away on 1 June 1970 at Regina by Jim and Shirley Jowsey (Blue Jay 28:120, 1970).

24. KISKADEE FLYCATCHER. NEW. One seen well on 19 May 1979 in Saskatoon by Pat O'Neil (Saskatoon Field Notes 29:9, 1979). This distinctive bird is not expected north of Texas and is not subject to irruptions, so an escape of a captive bird must be considered.

25. PINYON JAY. On first check-list. One sighting 16 September 1910 near Eastend by Laurence B. Potter (Can. FieldNat. 57:70, 1943).

26. MOUNTAIN CHICKADEE. On fifth list. One present at feeder 30 November, 3 December, daily from 5 December 1966 through end of March 1967 and on 5 days in April to the 22nd at Skull Creek by S.A. Mann (Blue Jay 27:126, 1969).

27. BRIDLED TITMOUSE. NEW. Seen on 16 May 1978 at feeder from 10 feet at Kenosee by Ruth Carson, a keen Audubon member from Yelm, Washington, and a former college biology teacher. This was reported in Doug Gilroy's "Prairie Wildlife" column in Western Producer, 12 June 1980, and again on 19 February 1981. In a letter to C.S. Houston on 21 March 1981, Mrs. Carson says she saw the crest clearly and thought first of Tufted Titmouse which she had known in the east, but the distinct face and throat markings were those of a Bridled Titmouse, checked at the time in Robbins, Bruun and Zim's guide. The bird stayed for 3 days. It was also seen by the excited owners of the feeder, Walter and Ruth Dixon. This species should not be closer than Arizona and New Mexico, and an escapee must again be considered - but from where?

28. DIPPER. Since third list, but sightings date from 1917. Twice seen at Ravenscrag including two by Spencer Pearse 22 May 1917 , a third sighting there by Bob Friel on 8 February 1941 (Houston, Bard and Nero, Blue Jay 16:65, 1958); Sealy, (Blue Jay 29:187, 1971); on 25 October 1963 on the main street of Maple Creek by R.V. Folker, Hugo Maliepaard and C. Reid (Blue Jay 22:5, 1964); on 6 May 1969 west of Eastend by Elizabeth Cruickshank and Ruth Baker; and on 9 May 1969 in Cypress Hills Park by Sharon Haggerty (Blue Jay 27:154, 1969).

29. CANYON WREN. NEW. One sang and was seen by R.D. Symons for 2 days in June 1941 in the Battle Creek valley of the Cypress Hills. (Hours and the Birds, 1967, p. 162).

30. BENDIRE'S THRASHER. NEW. 27 May 1972 west of Hanley by J.B. and M.F. Gollop (Blue Jay 33:167, 1975). This was the first Canadian sight record. The second was by D.R.M. Hatch and nine other observers at Grand Beach, Manitoba on 14 May 1974 (Houston and Shadick, Am. Birds 28:816, 1974).

31. WOOD THRUSH. NEW. There were seven sightings through the end of 1980: 24 May 1973 in Saskatoon by Pat O'Neil and nine others (Blue Jay 32:46, 1974); 5 October 1973 in Regina by E.L. Fox (Blue Jay $32: 46,1974) ; 27-28-29$ April 1974 in Saskatoon by Pat O'Neil (Blue Jay 33:189, 1975); 27 May 1976 at Biggar by G.J. and R.D. Wapple, well studied at 15 feet for 20 minutes (Blue Jay 35:159, 1977); 21 July 1976 by V.B. Scott and 28 September 1976, by Pat O'Neil, both in Saskatoon (Saskatoon Field Notes 20:8, 1976); 21 September 1979 near Colgate by D.G. Bobbitt as close as 10 feet for 10 minutes (Blue Jay 39:112, 1981). (There has since been an authenticated photograph taken on 11 \& 12 May, 1981 by Tom Riffel in Regina to place this species on the full Saskatchewan list.) 


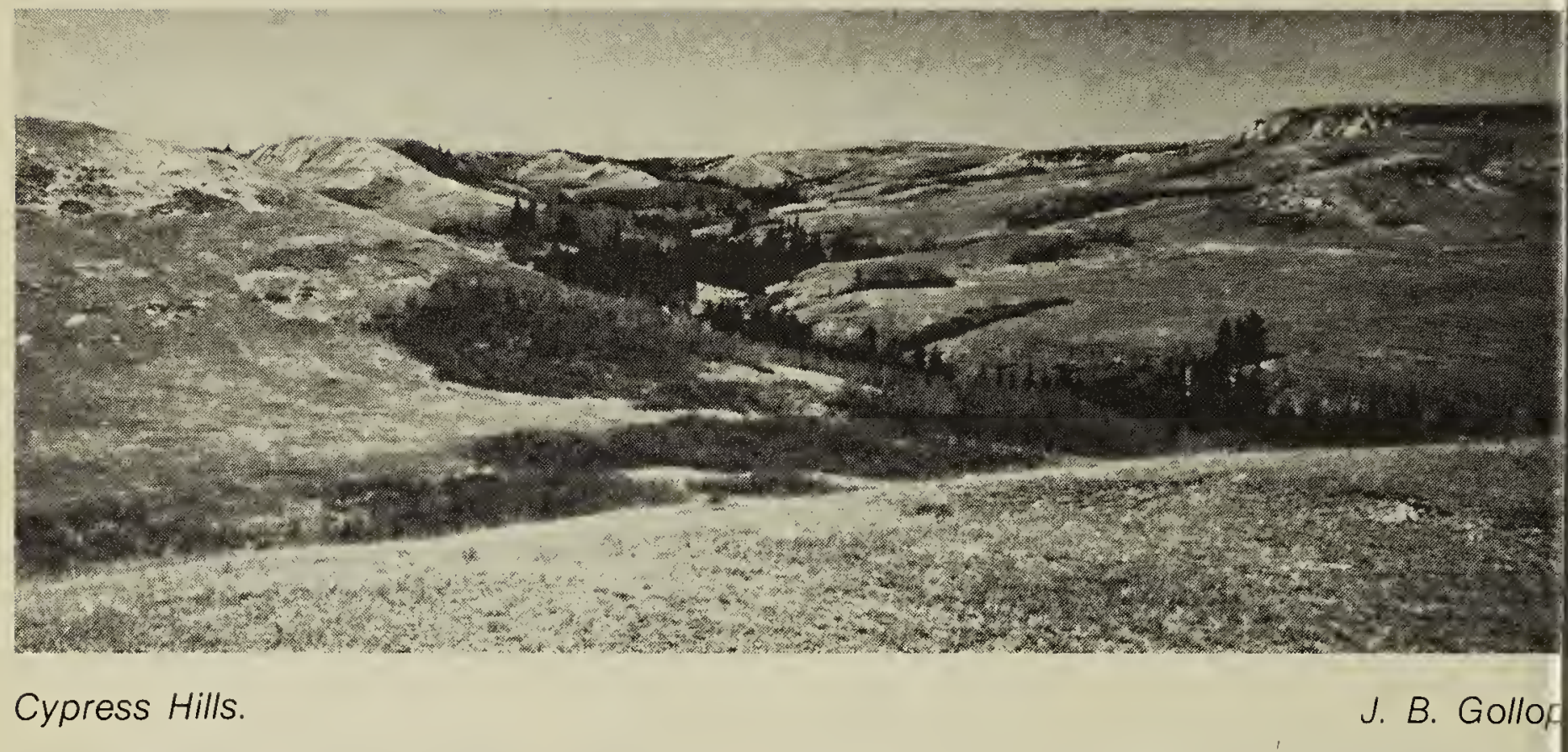

32. WESTERN BLUEBIRD. NEW. An adult male (with a female bluebird) on 1 September $19695 \mathrm{mi}$ south of Saskatoon by J.B. Gollop. Studied at distance of 40 yards with $7 \times 50$ binoculars for more than a minute; some red on back as well as on its breast. (Saskatoon Bird Review 4:119, 1969).

33. PROTHONOTARY WARBLER. On fifth list. A male in spring plumage on 17 May 1969 in Regina by D.G. Bobbitt and H.B. Bedard (Blue Jay 27:149,155, 1969), and on 13 September 1978 an adult male singing at Regina, observed by Robert Kreba for several minutes and detailed notes made (Serr, Am. Birds 33:190, 1979).

34. WORM-EATING WARBLER. NEW. 19 May 1979 in Saskatoon by Muriel and Geoff Galloway, Jim Slimmon and Mary Houston; photo taken but not identifiable. (Blue Jay 37:209, 1979).

35. TOWNSEND'S WARBLER. NEW with BREEDING EVIDENCE. Two adults feeding two recently fledged young on 18 July 1979 at Fort Walsh by Wayne C. Harris (Blue Jay 38:92, 1980); also a male on 7 September 1975 in Saskatoon by S.J. \& Mary Shadick (Blue Jay 34:102, 1976).

36. YELLOW-THROATED WARBLER. NEW. A pair on 16 May 1970 in Weyburn by Robert Kreba and Farrell Hall was well described (Blue Jay 29:130-131, 1971). An earlier report by Arthur Ward of banding this species in 1949 was probably a misidentification (Blue Jay $7(3): 8,1949$ ).

37. KENTUCKY WARBLER. NEW. On 25 September 1971 at Moose Jaw by John C. Horton and Dorothy Rhodes; studied at close range for 2 hours (Houston, Am. Birds 26:80 1972).

38. BLUE GROSBEAK. NEW. A pai sighted briefly on 26 May 1974 near Pike Lake by Jim and Thelma Pepper (Blue Ja) 33:168, 1975).

39. HOUSE FINCH. NEW. Four reports: male on 15 October 1959 in Saskatoon b) L.G. Saunders (Blue Jay 17:158, 1959) three males feeding on 26 April 1973 a Regina by Fred \& Phyllis Bard (Blue Ja) $32: 48,1974)$; a male within 6 feet on 6 February 1976 in Saskatoon by Pat O'Ne (Blue Jay 34:127-128, 1976); one female from $7 \mathrm{~m}$ on 29 April 1978 at Fort Qu'Appelle by E.M. Callin and F.H. Brazier (Callin, Bird: of the Qu'Appelle, 1857-1979, 1980, p. 144)

40. MCKAY'S BUNTING. NEW. A brie view of an adult male on 2 October 1978 in Regina by F.H. Brazier (Blue Jay 38:36-38 1980).

\section{REJECTED SPECIES}

1. AMERICAN FLAMINGO. One wa photographed from the air, by R. Kent Brace while conducting an aerial waterfowl censu near Lake Lenore on 3 October 1972. It wa learned that two bright flamingos had es caped from the Roosevelt Park Zoo at Mino North Dakota, on 25 September 1972, an one of them had been sighted $30 \mathrm{~m}$ northwest of Minot on 27 September. Th Lenore bird was also bright pink and the bes assumption is that it was one of the escapee and thus not a wild bird. For this reason th record has been rejected. Reminiscences $c$ 
